\title{
Fundamental properties of industrial hybrid cement: utilization in ready-mixed concretes and shrinkage-reducing applications
}

\author{
P. Martauz $z^{\mathrm{a}}$, I. Janotka ${ }^{\mathrm{b}} \bowtie$, J. Strigáćc ${ }^{\mathrm{a}}$, M. Bačuvčík ${ }^{\mathrm{b}}$ \\ a. Cement plant - Považská cementáreň, a.s., Ladce, (Ladce, Slovakia) \\ b. Building Testing and Research Institute, (Bratislava, Slovakia) \\ \janotka@tsus.sk
}

\author{
Received 3 June 2015 \\ Accepted 7 October 2015 \\ Available on line 19 May 2016
}

\begin{abstract}
Utility properties of novel hybrid cement (H-Cement) are influenced by pozzolanic reaction of fly ash, latent hydraulic reaction of metallurgical slag together with the alkali activation of inorganic geopolymer based on precipitated waste water coming from bauxite residues. Content of Portland cement clinker is at maximum of 20 mass $\%$, the remaining portion consists of inorganic geopolymer. Up to $80 \%$ of $\mathrm{CO}_{2}$ emissions are saved by H-Cement manufacture compared to ordinary Portland cement (OPC). No heat treatment or autoclaving is needed at $\mathrm{H}$-Cement production. The field application of $\mathrm{H}$-Cement is performed by the same way than that of common cements listed in EN 197-1, and is also connected with highly efficient recovery and safe disposal of red mud waste. H-Cement is suitable for ready-mixed concretes up to C30/37 strength class and is specified by beneficial shrinkage-reducing property of the concrete kept in long dry-air cure opposite to common cements.
\end{abstract}

KEYWORDS: Hybrid cement; Alkaline waste waters; Ready-mixed concretes; Shrinkage-reducing cement

Citation/Citar como: Martauz, P.; Janotka, I.; Strigáč, J.; Bačuvčík, M. (2016) Fundamental properties of industrial hybrid cement: utilization in ready-mixed concretes and shrinkage-reducing applications. Mater. Construcc. 66 [322], e084 http://dx.doi.org/10.3989/mc.2016.04615.

RESUMEN: Características básicas de un cemento híbrido industrial: utilización en hormigón premezclado y aplicaciones como reductor de la retracción. Las propiedades de un nuevo cemento híbrido (cemento-H) vienen determinadas por la reaccion puzolánica de cenizas volantes, la hidráulica latente de las escorias metalúrgicas y la activación alcalina mediante las aguas residuales generadas por el tratamiento de la bauxita para dar un geopolímero inorgánico. La proporción máxima de clínker de cemento en este nuevo material es del 20\%, y por ello, en su fabricación se emite hasta un $80 \%$ menos de $\mathrm{CO}_{2}$ que en la producción del cemento portland (OPC). El cemento-H se prepara sin necesidad de tratamiento térmico ni de estancia en autoclave y su aplicación es la misma que los cementos convencionales definidos en la norma EN 197-1. Por otra parte, su fabricación supone la recuperación y la valorización segura de los lodos rojos de bauxita. El cemento-H es apto para la preparación de hormigones premezclados hasta la categoría C30/37, presentando el nuevo material, además, una menor retracción que los cementos convencionales, por lo que su empleo resulta especialmente ventajoso en los hormigones que se curan al aire.

PALABRAS CLAVE: Cemento híbrido; Aguas residuales alcalinas; Hormigón premezclado; Cemento reductor de la retracción

Copyright: (C) 2016 CSIC. This is an open-access article distributed under the terms of the Creative Commons Attribution-Non Commercial (by-nc) Spain 3.0 License. 


\section{INTRODUCTION}

World cement production represented approximately 4 billion tonnes in 2013 (1). About 4.2 GJ energy is required to produce 1 tonne of OPC resulting in approximately $0.8-1.0$ tonne of $\mathrm{CO}_{2}$ released into the atmosphere (2). Global annual production of cement thus accounts for about $5 \%$ of the total anthropogenic $\mathrm{CO}_{2}$ emission (3). A second problem aside from $\mathrm{CO}_{2}$ emissions, which is worthy of a serious consideration is connected with the negative ecological and health impact of red and brown mud ponds containing high alkaline wastewater rich in $\mathrm{NaOH}$. The large environmental accidents like the one in Hungary in 2010 may occur during the storage of such waste (4). The land filled by this hazardous waste also raises other problems occurred due to the high concentrations of the heavy metals present and the variety of chemical compositions, depending on a large extent on season and weather conditions. High alkalinity can be neutralized by addition of $\mathrm{H}_{2} \mathrm{SO}_{4}$ and $\mathrm{CO}_{2}$ with subsequent formation of either $\mathrm{Na}_{2} \mathrm{SO}_{4}$ or $\mathrm{Na}_{2} \mathrm{CO}_{3}(5)$.

The main task of the research in recent times is the development of less energy intensive and more environmentally acceptable cements with highly efficient recovery and safe disposal of wastes and industrial by-products such as fly ashes from power and heating plants, metallurgical slags - mainly granulated blast furnace slag (GBFS), highly alkaline wastewaters from red mud ponds as well as sulphuric acid from car battery recovery (6).

One of potential solutions is the production of new cement binders, like alkali-activated cements (geopolymers) and hybrid alkali cements with Portland clinker addition $(7,8)$. Hybrid alkali cements have various compositions of alkali-activated alumino silicates with low Portland cement clinker content (9). Despite of low clinker content, the hybrid binders can also attain useful early mechanical strengths (10).

Typical mixtures of hybrid binders are composed of Portland cement clinker, usually less than 30 of mass \% with fly ash activated by $\mathrm{Na}_{2} \mathrm{SO}_{4}$ and $\mathrm{Na}_{2} \mathrm{CO}_{3}$ (11); metakaolin and clinker activated by $\mathrm{Na}_{2} \mathrm{SO}_{4}$ (12); blast furnace slag, metakaolin and clinker activated by $\mathrm{Na}_{2} \mathrm{CO}_{3}$ and $\mathrm{K}_{2} \mathrm{CO}_{3}$ (13); the mixture of fly ash, OPC and $\mathrm{Ca}(\mathrm{OH})_{2}$ activated by a calcined mixture of kaolin with $\mathrm{NaOH}$ or $\mathrm{KOH}$ (14). The activators $\mathrm{Na}_{2} \mathrm{CO}_{3}, \mathrm{~K}_{2} \mathrm{CO}_{3}, \mathrm{Na}_{2} \mathrm{SO}_{4}$ and $\mathrm{K}_{2} \mathrm{SO}_{4}$ are not characterized by highly alkalinity.

High-alkaline $\mathrm{NaOH}$ is generated at the presence of $\mathrm{Ca}(\mathrm{OH})_{2}$, which is the reaction product of on-going Portland cement clinker hydration. The alkalinity of the bulky cement matrix increases and creates favourable conditions for the consequent geopolymerisation process by means of high alkaline $\mathrm{NaOH}$ as shown in equations [1] and [2]:

$$
\begin{gathered}
\mathrm{Ca}(\mathrm{OH})_{2}+\mathrm{Na}_{2} \mathrm{CO}_{3} \rightarrow \mathrm{CaCO}_{3}+2 \mathrm{NaOH} \\
\mathrm{Ca}(\mathrm{OH})_{2}+\mathrm{Na}_{2} \mathrm{SO}_{4}+2 \mathrm{H}_{2} \mathrm{O} \rightarrow \mathrm{CaSO}_{4} \\
\times 2 \mathrm{H}_{2} \mathrm{O}+2 \mathrm{NaOH}
\end{gathered}
$$

Calcite $\mathrm{CaCO}_{3}$ (Eq. 1) and gypsum $\mathrm{CaSO}_{4} \times 2 \mathrm{H}_{2} \mathrm{O}$ (Eq. 2) are generated as by-products. The interaction of gypsum with $\mathrm{C}_{3} \mathrm{~A}$ present in Portland cement clinker results in the formation of ettringite $\mathrm{C}_{3} \mathrm{~A} \times 3 \mathrm{CaSO}_{4} \times 32 \mathrm{H}_{2} \mathrm{O}$ as demonstrated by equation [3]:

$$
\begin{gathered}
\mathrm{C}_{3} \mathrm{~A}+3 \mathrm{CaSO}_{4} \times 2 \mathrm{H}_{2} \mathrm{O}+26 \mathrm{H}_{2} \mathrm{O} \rightarrow \mathrm{C}_{3} \mathrm{~A} \\
\times 3 \mathrm{CaSO}_{4} \times 32 \mathrm{H}_{2} \mathrm{O}
\end{gathered}
$$

Reaction mechanism (Eq. 1) is quicker but yields calcite only, while the presence of sulphate ions promotes ettringite formation and consequently a denser matrix with the increased early strength (11).

GBFS and siliceous fly ash are predominantly vitreous materials with amorphous structures dissolved in the presence of alkaline $\mathrm{NaOH}, \mathrm{Na}_{2} \mathrm{SiO}_{3}$, $\mathrm{Na}_{2} \mathrm{SO}_{4}$ and $\mathrm{Na}_{2} \mathrm{CO}_{3}$ or $\mathrm{KOH}, \mathrm{K}_{2} \mathrm{SiO}_{3}, \mathrm{~K}_{2} \mathrm{SO}_{4}$ and $\mathrm{K}_{2} \mathrm{CO}_{3}$. After dissolution, alkali-activated alumino silicates, geopolymers are formed. Geopolymers possess a three-dimensional structure expressed by the formula $\mathrm{Me}_{\mathrm{n}}\left[-\left(\mathrm{SiO}_{2}\right)_{\mathrm{z}}-\mathrm{AlO}_{2}\right]_{\mathrm{n}} \times \mathrm{wH}_{2} \mathrm{O}$, where $M e$ is $\mathrm{Na}^{+}(\mathrm{N})$ or $\mathrm{K}^{+}(\mathrm{K})$, which in the framework balances the negative charge of $\mathrm{Al}(\mathrm{OH})_{4-} ; n$ is the degree of polycondensation and $z$ means 1,2,3 or $>>3$ (15). As a result, N-A-S-H or K-A-S-H gels are formed, which in the presence of Portland clinker may contain some amount of $\mathrm{Ca}$ to get a (C)-N-A-S-H gel. The curing conditions of fresh geopolymers are very important. After a short period, commonly between 6 and 12 hours of steam autoclaving or curing in dry air of about $60^{\circ} \mathrm{C}$ to $80^{\circ} \mathrm{C}$, the three-dimensional structure of the geopolymers gets stronger. In contrast, hydration of the Portland cement clinker results predominantly in the formation of C-S-H gels, whose microstructure contain some amount of Al to get C-(A)-S-H gels and portlandite $\mathrm{Ca}(\mathrm{OH})_{2}$ formed to a smaller extent. Portlandite promotes the pozzolanic properties of fly ashes to get secondary $\mathrm{C}-\mathrm{S}-\mathrm{H}$ and $\mathrm{C}-\mathrm{A}-\mathrm{H}$ gels and the latent hydraulic properties of granulated blast furnace slag to produce secondary C-(A)-S-H gels. Solid solutions of hydrotalcite minerals of $\mathrm{Mg}_{6} \mathrm{Al}_{2} \mathrm{CO}_{3}(\mathrm{OH})_{16} \times 4 \mathrm{H}_{2} \mathrm{O}$ kind and $\mathrm{C}_{4} \mathrm{AH}_{13}$, the hydrogarnets $\mathrm{C}_{3} \mathrm{AS}_{3-\mathrm{n}} \mathrm{H}_{\mathrm{n}}$ and $\mathrm{C}_{6} \mathrm{AFS}_{2} \mathrm{H}_{8}$, strätlingite $\mathrm{C}_{2} \mathrm{ASH}_{8}$, ettringite and sometimes carboaluminates $\mathrm{C}_{3} \mathrm{~A} \cdot \mathrm{CaCO}_{3} \mathrm{H}_{11}$ are also created.

Novel hybrid cement binders therefore contain both kinds of gels, C-(A)-S-H as well as (C)-N-A$\mathrm{S}-\mathrm{H}$, whose collective chemical interaction results in the formation of a final (N,C)-A-S-H gel (11). Recently it has been found that hybrid cements based on a high content of fly ash from coal combustion (>70 mass \%) and low content of Portland 
cement clinker in the presence of an alkaline activator give rise to the development of three different gel-bonding environments, tentatively attributed to C-(A)-S-H, C-A-S-H and (N,C)-A-S-H type gels (16). The related findings showed that the C-S-H/N-A-S-H mixture of the formed gels did not precipitate in a pure state but rather that their composition was affected by the presence of dissolved species (17). In the presence of aluminium $\mathrm{C}-\mathrm{S}-\mathrm{H}$ gel development is specified by next developmental sequence: C-S-H $\rightarrow$ C-(A)-S-H $\rightarrow$ C-A-S-H. In the presence of calcium, the N-A-S-H gel evolved as: N-A-S-H $\rightarrow$ (N, C)-A-S-H $\rightarrow$ C-A-S-H. This last conversion is not complete in these systems because the amount of calcium present is thought to be insufficient (17). Due to the intensive formation of gel-like hydration products hybrid cements are more chemically resistant to aggressive media in comparison with traditional OPC (18-20). The main disadvantage of ordinary geopolymers based on N-A-S-H or K-A-S-H gels lies in the relatively short initial setting time, which is being reduced by increasing alkalinity and steam autoclaving or dry curing. Contrary, their significant benefit is very high heat and fire resistance up to temperature elevation of $1100{ }^{\circ} \mathrm{C}(21)$. According to the gained knowledge (19), original strength of hybrid cement is almost doubled after the exposure to $800{ }^{\circ} \mathrm{C}$ and even to $1000{ }^{\circ} \mathrm{C}$ in contrast with OPC showing steady and continual strength losses as the temperatures rise up.

The second disadvantage of ordinary geopolymers based on the N-A-S-H or K-A-S-H gels that one has to take into the consideration lies in the increased susceptibility to shrinkage (22). Water glass-activated slag mortars and concretes are usually characterized by substantial autogenous and drying shrinkage, which represent a restriction of the widespread use of alkali-activated slag systems as alternative binders to traditional OPC in the structural elements (22). The shrinkage-reducing admixture based on polypropylenglycol reduces autogenous shrinkage by $85 \%$ and drying shrinkage by $50 \%$ in water glass-activated slag mortars (22).

Shrinkage is characteristic feature for geopolymer and OPC-based concrete. Shrinkage-reducing admixture such as ye'elimite $3 \mathrm{CA} . \mathrm{CaSO}_{4}$; or calcium sulphoaluminate cements based on 3CA. $\mathrm{CaSO}_{4}, \mathrm{C}_{2} \mathrm{~S}, \mathrm{CaSO}_{4}$ and $\mathrm{CaO}$ or a mixture of $\mathrm{C}_{3} \mathrm{~A}$ and $\mathrm{CaSO}_{4}$ or a mixture of calcium aluminate cement $\mathrm{CA}$ and $\mathrm{CaSO}_{4}$, which provide the formation of expansive ettringite or a mixture of hard-burnt $\mathrm{CaO}$ and $\mathrm{H}_{2} \mathrm{O}$ providing expansive $\mathrm{Ca}(\mathrm{OH})_{2}$ can be applied in the concrete as the expansive addition. Hybrid cement takes advantage of material properties of traditional cement and inorganic geopolymer resulting in such benefits of utility properties that the hybrid cement can partly replace energy- and environmentally-intensive OPC (23).

This paper is focus on the basic properties of ready-mixed concretes containing hybrid cement. Expansion-reducing and mainly shrinkage-reducing properties of $\mathrm{H}$-Cement in concrete cured either in water at temperature of $20 \pm 1{ }^{\circ} \mathrm{C}$ or dry air conditions of $20{ }^{\circ} \mathrm{C} / 60 \% \mathrm{R}$. H. and $40{ }^{\circ} \mathrm{C} / 15 \% \mathrm{R} . \mathrm{H}$ are next important observations of this article.

\section{MATERIALS}

The novel hybrid cement (H-Cement) is composed of fly ash, granulated blast furnace slag (GBFS) and the highly alkaline waste water concentrate from red mud deposit as well as 20 mass \% of Portland cement clinker. Chemical compositions of H-Cement and its raw material components are reported in Table 1 and Table 2, respectively.

The composition of $\mathrm{H}$-Cement was adjusted on the minimum content of $\mathrm{SiO}_{2}, \mathrm{CaO}, \mathrm{SO}_{3}$ and $\mathrm{Na}_{2} \mathrm{O}$ of 40.0 mass $\%, 20.0$ mass $\%, 3.0$ mass $\%$ and 2.0 mass $\%$, respectively. Highly alkaline waste water

TABLE 1. Chemical composition of H-Cement (abbreviated as HC) and its main solid components

\begin{tabular}{lccccccccc}
\hline (mass. \%) & $\mathbf{C a O}$ & $\mathbf{S i O}_{\mathbf{2}}$ & $\mathbf{A l}_{\mathbf{2}} \mathbf{O}_{\mathbf{3}}$ & $\mathbf{F e}_{\mathbf{2}} \mathbf{O}_{3}$ & $\mathbf{M g O}$ & $\mathbf{S O}_{\mathbf{3}}$ & $\mathbf{K}_{\mathbf{2}} \mathbf{O}$ & $\mathbf{N a}_{\mathbf{2}} \mathbf{O}$ & $\mathbf{L}$.O.I. \\
\hline HC & 22.55 & 43.55 & 17.52 & 5.86 & 2.68 & 3.85 & 2.74 & 2.49 & 1.51 \\
Clinker & 66.13 & 21.69 & 5.31 & 2.83 & 1.44 & 0.53 & 1.00 & 0.04 & 0.85 \\
GBFS & 39.24 & 40.13 & 7.19 & 0.27 & 10.04 & 1.50 & 0.52 & 0.31 & 1.10 \\
Fly Ash & 3.36 & 51.42 & 26.93 & 7.27 & 2.10 & 0.87 & 3.28 & 0.17 & 1.84 \\
\hline
\end{tabular}

Notice: L.O.I. means loss on ignition

TABLE 2. Chemical composition of highly alkaline wastewater from red mud pond as standard water from the pond (Standard) and concentrate water from the evaporator (Concentrate)

\begin{tabular}{lccccccccc}
\hline $\mathbf{( m g / l )}$ & $\mathbf{C a}$ & $\mathbf{S i}$ & $\mathbf{A l}$ & $\mathbf{F e}$ & $\mathbf{M g}$ & $\mathbf{N a}$ & $\mathbf{K}$ & $\left.\mathbf{( S O}_{\mathbf{4}}\right)^{\mathbf{2}}$ & $\mathbf{p H}$ \\
\hline Standard & 6.9 & 59.8 & 538 & 0.64 & 1.9 & 11820 & 156 & 4072 & 13.0 \\
Concentrate & 12.5 & 189 & 2143 & 26.0 & 4.4 & 53990 & 710 & 24098 & 13.2 \\
\hline
\end{tabular}


concentrate was obtained by the evaporation and electrodialysis of standard waste water occurring in the deposit. The concentrate was neutralised by sulfuric acid $\mathrm{H}_{2} \mathrm{SO}_{4}$ with precipitation of solid $\mathrm{Na}_{2} \mathrm{SO}_{4}$. The measured $\mathrm{pH}$ values before and after neutralisation were 13 and 5 to 7 , respectively. The XFR analysis confirmed 99 mass \% chemical purity of $\mathrm{Na}_{2} \mathrm{SO}_{4}$ when using apparatus SPECTRO X-LAB 2000. Main minerals containing fly ash are quartz $\mathrm{SiO}_{2}$, mullite $3 \mathrm{Al}_{2} \mathrm{O}_{3} \times 2 \mathrm{SiO}_{2}$, hematite $\mathrm{Fe}_{2} \mathrm{O}_{3}$ and magnetite $\mathrm{Fe}_{3} \mathrm{O}_{4}$. GBFS consists mainly of $90 \%$ vitreous phase. The content of GBFS in the hybrid cement was estimated by microscope counting method. The sample, taken from a particular GBFS size fraction is examined in transmitted light (magnification degree 100) and counts at least one thousand slag grains in all. The GBFS grains of glassy fracture are clear, homogeneous and transparent for light. The GBFS grains of crystalline phase are darker not fully transparent. The calculation is as follows: $\%$ of glassy phase in GBFS=(Number of glassy, transparent grains of GBFS/Total number of all grains of GBFS) $\times 100$. The portion of glassy phase was also checked by the procedures specified in CEN/TR (24) and EN Standard (25). H-Cement contains 19.3 mass $\%$ and OPC $87.59 \%$ of clinker minerals Mineralogical composition, determined by XRD technique at BRUKER AXS D8 Advance device supplemented by Rietveld analysis $(26,27)$ of both cements is reported in Table 3 .

Portlandite $\mathrm{Ca}(\mathrm{OH})_{2}(\mathrm{CH})$ is slowly formed from free lime $\mathrm{C}_{\text {free }}$ due to partial hydration by air humidity. Next abbreviations mean quartz $\mathrm{SiO}_{2}(\mathrm{Q})$, free lime $\mathrm{CaO}\left(\mathrm{C}_{\text {free }}\right)$, cubic $\mathrm{C}_{3} \mathrm{~A}\left(\mathrm{C}_{3} \mathrm{Ac}\right)$, orthorhombic $\mathrm{C}_{3} \mathrm{~A}\left(\mathrm{C}_{3} \mathrm{Ao}\right)$, periclase $\mathrm{MgO}(\mathrm{M})$. The expression ${ }^{x} \mathrm{CaSO}_{4}$ gives the total sum of 4.44 mass $\%$ gypsum $\left(\mathrm{CaSO}_{4} \times 2 \mathrm{H}_{2} \mathrm{O}\right)+2.42$ mass $\%$ bassanite $\left(\mathrm{CaSO}_{4} \times 0.5 \mathrm{H}_{2} \mathrm{O}\right)+1.52$ mass $\%$ anhydrite $\left(\mathrm{CaSO}_{4}\right)$ +0.28 mass \% calcite $\left(\mathrm{CaCO}_{3}\right)$, which are the main constituents of calcium sulphate used as the setting time regulator. The total amount of crystalline phases coming from clinker minerals in H-Cement is 20.0 mass $\%$. Majority portion is constituted by the amorphous inorganic geopolymer, which is not detectable by XRD technique. The total content of crystalline phases of OPC clinker minerals is 91.34 mass $\%$ opposite to that of $\mathrm{H}$-Cement showing only 20 mass \% occurrence of crystalline phases of clinker origin.

\section{RESULTS AND DISCUSSION}

\subsection{Typical characteristic values of H-Cement}

Typical values of H-Cement and CEM I 42.5 $\mathrm{R}$ (OPC) are given in Table 4. H-Cement is characterized by early reduced and 28-days strengths and lower hydration heat compared to OPC. The low hydration heat predestines $\mathrm{H}$-Cement for use in a similar way than the cements with low hydration heat according to EN 14216 (28). Final setting of $\mathrm{H}$-Cement is slightly prolonged relative to that of OPC. This feature makes it also suitable for use in ready-mixed concretes by the same way as OPC.

TABLE 3. Mineral composition of H-Cement (HC) and OPC

\begin{tabular}{lccccccccccc}
\hline (mass \%) & $\mathbf{C}_{3} \mathbf{S}$ & $\mathbf{C}_{2} \mathbf{S}$ & $\mathbf{C}_{3} \mathbf{A c}$ & $\mathbf{C}_{3} \mathbf{A o}$ & $\mathbf{C}_{\mathbf{4}} \mathbf{A F}$ & $\mathbf{C}_{\text {free }}$ & $\mathbf{M}$ & $\mathbf{Q}$ & $\mathbf{K}_{2} \mathbf{S O}_{4}$ & $\mathbf{C H}$ & ${ }^{\mathbf{x}} \mathbf{C a S O}_{4}$ \\
\hline $\mathrm{HC}$ & 13.28 & 2.49 & 0.64 & 1.30 & 1.59 & 0.30 & 0.07 & 0.02 & 0.20 & 0.11 & - \\
OPC & 61.50 & 10.3 & 0.65 & 4.43 & 10.71 & 0.26 & 0.35 & 0.28 & 1.63 & 1.23 & 8.66 \\
\hline
\end{tabular}

TABLE 4. Characteristic values of $\mathrm{H}-\mathrm{Cement}$ and reference OPC

\begin{tabular}{llll}
\hline Technical parameters & Unit & H-Cement & OPC \\
\hline Initial setting time & $($ minute $)$ & $200 \pm 20$ & $190 \pm 20$ \\
Final setting time & $($ minute $)$ & $300 \pm 40$ & $250 \pm 30$ \\
Standard consistency & $(\%)$ & $32 \pm 2.0$ & $29.1 \pm 1.8$ \\
2 days compressive strength & $(\mathrm{MPa})$ & $17.5 \pm 3.0(\mathrm{w} / \mathrm{c}=0.4)$ & $33.7 \pm 2.0(\mathrm{w} / \mathrm{c}=0.5)$ \\
28 days compressive strength & $(\mathrm{MPa})$ & $36,5 \pm 4.0(\mathrm{w} / \mathrm{c}=0.4)$ & $59.2 \pm 1.6(\mathrm{w} / \mathrm{c}=0.5)$ \\
90 days compressive strength & $(\mathrm{MPa})$ & $41.5 \pm 3.0(\mathrm{w} / \mathrm{c}=0.4)$ & $63.1 \pm 1.9(\mathrm{w} / \mathrm{c}=0.5)$ \\
2 days flexural strength & $(\mathrm{MPa})$ & $3.5 \pm 0.5(\mathrm{w} / \mathrm{c}=0.4)$ & $6.4 \pm 0.4(\mathrm{w} / \mathrm{c}=0.5)$ \\
28 days flexural strength & $(\mathrm{MPa})$ & $4.4 \pm 0.4(\mathrm{w} / \mathrm{c}=0.4)$ & $8,9 \pm 0.4(\mathrm{w} / \mathrm{c}=0.5)$ \\
90 days flexural strength & $(\mathrm{MPa})$ & $9.0 \pm 0.3(\mathrm{w} / \mathrm{c}=0.4)$ & $9.3 \pm 0.3(\mathrm{w} / \mathrm{c}=0.5)$ \\
Soundness & $(\mathrm{mm})$ & 0.5 & 0.01 \\
Content of Cr ${ }^{\mathrm{VI}}$ & $(\mathrm{ppm})$ & 1.0 & 1.23 \\
Content of $\mathrm{C}_{3} \mathrm{~A}$ & $(\mathrm{mass} \%)$ & $2.0 \pm 0.5$ & $7.5 \pm 0.8$ \\
Hydration heat & $(\mathrm{J} / \mathrm{g})$ & 185 & 359 \\
\hline
\end{tabular}


H-Cement acts as a solid plasticizer due to high amounts of present fly ash and GBFS. The OPC mortars are prepared with $\mathrm{w} / \mathrm{c}=0.5$ according to EN 196-1 (29). H-Cement needs for the same slump w/c $=0.4$ only. According to EN 196-1 (29) water to cement ratio $>0.4$ leads to bleeding during vibration of fresh H-Cement mortar. This is the reason for which w/c of 0.4 has to be applied for manufacturing of H-Cement mortar instead of 0.5 for OPC mortars as prescribed in EN 196-1. Compressive strength uptakes indicate that $\mathrm{H}-\mathrm{Cement}$ at $\mathrm{w} / \mathrm{c}=0.4$ may be classified as the cement of $32.5 \mathrm{R}$ strength class according to EN 197-1 criteria (30). H-Cement is not classified by EN 197-1 criteria due to its composition but is presently specified by the issued Certificate of conformity and Technical approval $(31,32)$.

\subsection{H-Cement utilization in ready-mixed concretes}

Table 5 demonstrates the composition of readymixed concretes of different compressive strength classes according to EN 206-1 (33), which were measured according to EN 12390-3 (34) for reaching the constant consistence slump of class S3 $(100-150 \mathrm{~mm})$ as described in EN 12350-2 (35) without using a plasticizer. The plasticizing effect of $\mathrm{H}-\mathrm{C}$ ement in the fresh mixture was recognized in C20/25 strength class concrete with cement content of $400 \mathrm{~kg} / \mathrm{m}^{3}$ and w/c ratio of 0.475 (Table 5) and also in C30/37 strength class concrete with cement content of $350 \mathrm{~kg} / \mathrm{m}^{3}$ and $\mathrm{w} / \mathrm{c}$ ratio of 0.42 the class S3 consistency.

$\mathrm{H}$-Cement is suitable for ready-mixed concretes of strength classes up to C30/37 without use of any commercial plasticizer as admixture. The effect of different plasticizers on workability of fresh mixtures is shown on ready-mixed concrete of C20/25 strength class having the composition as stated in the $4^{\text {th }}$ raw of Table 5. Compositions of fresh C20/25 concretes with different kind of plasticizers with the same consistence slump class S5 are reported in Table 6.

Consistency of fresh concrete mixtures specified by the cone slump test according to EN 12350-2 (35) was adjusted to the value of $\mathrm{S} 5$ ( $\geq 220 \mathrm{~mm})$. Losses in consistency 60 minutes after mixing and cube compressive strengths are given in Table 7. Fresh concretes with use of a plasticizer showed slightly higher air contents than H-Cement concrete without plasticizer.

Following plasticizers were verified in the fresh concrete mixtures: M1 - no plasticizer as a chemical admixture, M2 - lignosulfonate, M3 - modified polycarboxylate (specific feature designed by a producer: less than $22 \%$ polycarboxylate content), M4 - polycarboxylate (30\% water - reducing effect), M5 - modified polycarboxylate (more than $22 \%$ polycarboxylate content), M6 - polycarboxylate (35\% water-reducing effect), M7 - melamine,

TABLE 5. Concrete compositions with H-Cement (HC) at the same consistence slump class S3

\begin{tabular}{|c|c|c|c|c|c|c|c|c|}
\hline \multirow{2}{*}{$\begin{array}{l}\text { Concrete } \\
\text { strength class }\end{array}$} & \multirow{2}{*}{$\begin{array}{c}\mathrm{HC} \\
\left(\mathrm{kg} / \mathrm{m}^{3}\right)\end{array}$} & \multirow{2}{*}{$\begin{array}{l}\text { Water } \\
\left(\mathrm{kg} / \mathrm{m}^{3}\right)\end{array}$} & \multicolumn{3}{|c|}{ Aggregates (mm) } & \multicolumn{3}{|c|}{ Strengths $\mathrm{f}_{\text {ck.cube }}(\mathrm{MPa})$} \\
\hline & & & $0-4$ & 4-8 & 8-16 & $2 f_{\text {ck.cube }}$ & $7 f_{\text {ck.cube }}$ & $28 f_{\text {ck.cubc }}$ \\
\hline $\mathrm{C} 8 / 10$ & 270 & 185 & 762 & 362 & 781 & 4.8 & 10.4 & 16.0 \\
\hline $\mathrm{C} 12 / 15$ & 300 & 190 & 707 & 372 & 781 & 5.7 & 11.4 & 18.7 \\
\hline $\mathrm{C} 16 / 20$ & 360 & 190 & 627 & 376 & 788 & 6.9 & 14.6 & 22.2 \\
\hline $\mathrm{C} 20 / 25$ & 400 & 190 & 592 & 361 & 773 & 8.0 & 16.8 & 25.0 \\
\hline $\mathrm{C} 30 / 37$ & 350 & 147 & 602 & 565 & 657 & - & - & 42.6 \\
\hline
\end{tabular}

TABLE 6. Composition of fresh $\mathrm{C} 20 / 25$ concretes with different kinds of plasticizers with the same consistence slump class S5

\begin{tabular}{lcccccc}
\hline $\begin{array}{l}\mathbf{C} \mathbf{2 0 / 2 5} \\
\left(\mathbf{k g} / \mathbf{m}^{\mathbf{3}}\right)\end{array}$ & H-Cement & Water & Plasticizer & $\begin{array}{c}\text { Aggregates } \\
\mathbf{0 - 4} \mathbf{~ m m}\end{array}$ & $\begin{array}{c}\text { Aggregates } \\
\mathbf{4 - 8} \mathbf{~ m m}\end{array}$ & $\begin{array}{c}\text { Aggregates } \\
\mathbf{8}-\mathbf{1 6} \mathbf{~ m m}\end{array}$ \\
\hline M1 & 400 & 220 & - & 753 & 263 & 735 \\
M2 & 400 & 212 & 3.0 & 753 & 263 & 735 \\
M3 & 400 & 217 & 2.0 & 753 & 263 & 735 \\
M4 & 400 & 217 & 2.0 & 753 & 263 & 735 \\
M5 & 400 & 215 & 2.0 & 753 & 263 & 735 \\
M6 & 400 & 201 & 2.0 & 753 & 263 & 735 \\
M7 & 400 & 216 & 3.0 & 753 & 263 & 735 \\
M8 & 400 & 228 & 3.0 & 753 & 263 & 735 \\
\hline
\end{tabular}

Notice: Plasticizers used for concrete manufacture are described in text relevant to Tables 6 and 7. 
TABLE 7. Properties of fresh concrete mixtures with different kinds of plasticizers and the cube compressive strengths $\mathrm{f}_{\text {ck.cube }}$ after 2, 28, 56 and 90 days

\begin{tabular}{|c|c|c|c|c|c|c|c|}
\hline \multirow[b]{2}{*}{$\begin{array}{l}\text { Concrete } \\
\text { C 20/25 }\end{array}$} & \multirow{2}{*}{$\begin{array}{c}\text { Entrapped } \\
\text { air after } \\
\text { mixing }(\%)\end{array}$} & \multicolumn{2}{|c|}{ Consistency - cone slump } & \multicolumn{4}{|c|}{ Cube compressive strengths $\mathbf{f}_{\text {ck.cube }}$} \\
\hline & & $\begin{array}{c}\text { after } \\
\text { mixing }(\mathbf{m m})\end{array}$ & $\begin{array}{l}\text { after } 60 \mathrm{~min} . \\
(\mathrm{mm})\end{array}$ & $\begin{array}{l}2 \mathbf{f}_{\text {ck.cube }} \\
\text { (MPa) }\end{array}$ & $\begin{array}{c}28 \mathbf{f}_{\text {ck.cube }} \\
\text { (MPa) }\end{array}$ & $\begin{array}{c}56 f_{\text {ck.cube }} \\
(\mathrm{MPa})\end{array}$ & $\begin{array}{c}90 \mathrm{f}_{\text {ck.cube }} \\
\text { (MPa) }\end{array}$ \\
\hline M1 & 1.2 & 220 & 120 & 11.0 & 23.6 & 24.8 & 26.3 \\
\hline M2 & 2.1 & 220 & 130 & 11.0 & 25.0 & 27.1 & 28.4 \\
\hline M3 & 1.7 & 220 & 60 & 10.6 & 21.8 & 22.5 & 22.6 \\
\hline M4 & 1.6 & 220 & 70 & 9.3 & 21.2 & 22.5 & 22.7 \\
\hline M5 & 1.7 & 220 & 110 & 10.1 & 23.6 & 26.6 & 25.4 \\
\hline M6 & 1.4 & 220 & 170 & 8.6 & 22.6 & 24.1 & 23.7 \\
\hline M7 & 2.3 & 220 & 40 & 7.1 & 24.0 & 24.6 & 29.9 \\
\hline M8 & 1.3 & 220 & 190 & 9.4 & 22.2 & 21.1 & 24.6 \\
\hline
\end{tabular}

M8 - lignosulfonate modified by polycarboxylate. Differences in batch water contents indicated in Table 6 for achieving the constant consistency of the class S5 are caused by use of different kinds and dosages of plasticizers. Table 7 reports higher air contents of fresh concretes with a plasticizer opposite to that with H-Cement only. Increased air contents and reduced w/c ratios in fresh mixtures with a plasticizer caused insignificant strength uptakes towards the compressive strength gain of $\mathrm{H}$-Cement concrete prepared without a plasticizer.

These valuable findings appeared from the test materials and employed test methods:

1.) H-Cement is suitable for ready-mixed concretes of strength class up to C30/37 without use of any plasticizer as chemical admixture.

2.) 2.) Lignosulfonates (M2) and polycarboxylates (M6) and mainly combined plasticizer on the lignosulfonate and polycarboxylate base (M8) are the most appropriate plasticizers for use in $\mathrm{H}$-Cement concrete due to the most prolonged workability 60-minutes after mixing a fresh mixture.

3.) H-Cement, currently located outside the compositions of common cements specified by EN 197-1 Standard (30), is applicable in ready-mixed concretes with the above two prescriptions by the same way as traditionally manufactured OPC.

\subsection{H-Cement utilization for shrinkage-reducing applications}

To verify the reduction of expansion in water and shrinkage in dry environments, the concretes were prepared from a cement mixture made of 2 kinds of cements (H-Cement and OPC) in the selected ratios (expressed as mass \%) according to Table 8 . Main difference between both cements is based on the content of clinker minerals: H-Cement and OPC contain 19.3 mass $\%$ and 87.59 mass $\%$, respectively.
An inorganic geopolymer occupies in $\mathrm{H}-\mathrm{Cement}$ 79.89 mass $\%$ portion (Table 3 ).

The measurements were performed within the 90-days exposure period in water at temperature of $20 \pm 1{ }^{\circ} \mathrm{C}$ according to STN 731311 (36) and in air at condition of $20{ }^{\circ} \mathrm{C} / 60 \% \mathrm{R}$.H. or $40{ }^{\circ} \mathrm{C} / 15 \%$ R.H. - dry cure. The exposure in temperature of $20 \pm 1{ }^{\circ} \mathrm{C} / 60 \%$ of R.H. - air meets the requirement put on curing regime of the above-mentioned standard. This curing is specified as normal laboratory environment. The air with $15 \%$ of R.H. at temperature of $40 \pm 2{ }^{\circ} \mathrm{C}$ was chosen for unambiguously specified dry environment evoking a high susceptibility of cement-based concrete to shrinkage.

In water the expansion of OPC was affected by small additions of $\mathrm{H}$-Cement ( 5 to 15 mass $\%$ ) to the cement mixture (in Table 8 marked as $\mathrm{PCH}$ $0.95, \mathrm{PCH} 0.90$ and $\mathrm{PCH} 0.85)$. Conversely, in dry exposures the reduction of OPC shrinkage was influenced by higher additions of H-Cement ( 85 to 95 mass \%) (in Table 8 shown as HPC 0.85, HPC 0.90 and HPC 0.95). Mutual ratio of 50 mass $\%$ of $\mathrm{H}$-Cement to 50 mass \% of OPC (HPC 0.50) represents the mean value between two marginal systems for a comparison to recognize the effects of both cements in equal portion $[100 \% \mathrm{H}$-Cement (HPC 1.00) and 100\% OPC (PCH 1.00)]. This cement mixture was kept in each of the chosen exposures (water at temperature of $20^{\circ} \mathrm{C}$, curing at temperature of $20{ }^{\circ} \mathrm{C} / 60 \%$ of R. H. and temperature of $40{ }^{\circ} \mathrm{C} / 15 \%$ of R. H. - dry air).

The abbreviations PCH or HPC used in Table 8 and Tables 10 to 12 and Figures 1 to 6 indicate a cement mixture prepared by mixing cements (C) in a certain proportion of $\mathrm{H}$-Cement $(\mathrm{H})$ to OPC (P). $\mathrm{PCH}$ is a mixed system with a higher content of P (OPC), while HPC has a higher content of $\mathrm{H}$ (H-Cement). The concretes were prepared with a constant water to cement ratio of w/c $=0.475$ according to the mixture proportion: $400 \mathrm{~kg} / \mathrm{m}^{3}$ of cement or cement mixture, 190 litres of water, dried river aggregates: $0 / 4 \mathrm{~mm}-630 \mathrm{~kg}$ per $1 \mathrm{~m}^{3}, 4 / 8 \mathrm{~mm}-390 \mathrm{~kg}$ per 
Fundamental properties of industrial hybrid cement: utilization in ready-mixed concretes and shrinkage-reducing applications $\bullet 7$

TABLE 8. Content of cements in the mixtures according to curing regime of the concrete

\begin{tabular}{|c|c|c|c|}
\hline \multirow{2}{*}{$\begin{array}{l}\text { Cement } \\
\text { mixture }\end{array}$} & \multicolumn{2}{|c|}{ Content of cements (mass \%) } & \multirow[b]{2}{*}{ Curing regime } \\
\hline & H-Cement & OPC & \\
\hline PCH 1.00 & 0 & 100 & in water at $20^{\circ} \mathrm{C}$ and in air at $20^{\circ} \mathrm{C}$ and $40^{\circ} \mathrm{C}$ \\
\hline PCH 0.95 & 5 & 95 & in water at $20^{\circ} \mathrm{C}$ \\
\hline РCH 0.90 & 10 & 90 & \\
\hline PCH 0.85 & 15 & 85 & \\
\hline HPC 0.50 & 50 & 50 & in water at $20^{\circ} \mathrm{C}$ and in air at $20^{\circ} \mathrm{C}$ and $40^{\circ} \mathrm{C}$ \\
\hline HPC 0.85 & 85 & 15 & in air at $20^{\circ} \mathrm{C}$ and $40^{\circ} \mathrm{C}$ \\
\hline HPC 0.90 & 90 & 10 & \\
\hline HPC 0.95 & 95 & 5 & \\
\hline HPC 1.00 & 100 & 0 & in water at $20^{\circ} \mathrm{C}$ and in air at $20^{\circ} \mathrm{C}$ and $40^{\circ} \mathrm{C}$ \\
\hline
\end{tabular}

Notice: Content of cements in the cement mixtures in mass \% (expressed as $\mathrm{HC} / \mathrm{PC}$ ratios) according to curing regimes of the concrete are as follows:

- PCH $1.00(0 / 100)$ in water at $20^{\circ} \mathrm{C}$ and in air at $20^{\circ} \mathrm{C}$ and $40{ }^{\circ} \mathrm{C}$

- $\mathrm{PCH} 0.95(5 / 95)$ in water at $20^{\circ} \mathrm{C}$

- PCH $0.90(10 / 90)$ in water at $20^{\circ} \mathrm{C}$

- PCH $0.85(15 / 85)$ in water at $20^{\circ} \mathrm{C}$

- HPC $0.50(50 / 50)$ in water at $20^{\circ} \mathrm{C}$ and in air at $20^{\circ} \mathrm{C}$ and $40{ }^{\circ} \mathrm{C}$

- HPC $0.85(85 / 15)$ in air at $20^{\circ} \mathrm{C}$ and $40^{\circ} \mathrm{C}$

- HPC $0.90(90 / 10)$ in air at $20^{\circ} \mathrm{C}$ and $40{ }^{\circ} \mathrm{C}$

- HPC $0.95(95 / 5)$ in air at $20^{\circ} \mathrm{C}$ and $40{ }^{\circ} \mathrm{C}$

- HPC $1.00(100 / 0)$ in water at $20^{\circ} \mathrm{C}$ and in air at $20^{\circ} \mathrm{C}$ and $40{ }^{\circ} \mathrm{C}$

TABLE 9. Rheological properties, volume density and 2-days strength of two outer concrete mixtures

\begin{tabular}{lcccc}
\hline $\begin{array}{l}\text { Fresh } \\
\text { concrete }\end{array}$ & $\begin{array}{c}\text { Consistency } \\
(\mathbf{m m})\end{array}$ & $\begin{array}{c}\text { Volume density } \\
\left(\mathbf{k g} / \mathbf{m}^{\mathbf{3}}\right)\end{array}$ & $\begin{array}{c}\text { Air content } \\
(\mathbf{\%} \text { vol. })\end{array}$ & $\begin{array}{c}\text { 2-days compressive } \\
\text { strength (MPa) }\end{array}$ \\
\hline HPC 1.00 & 10.5 & 2380 & 1.3 & 10.1 \\
PCH 1.00 & 6.0 & 2420 & 1.1 & 19.3 \\
\hline
\end{tabular}

$1 \mathrm{~m}^{3}$ and $8 / 16 \mathrm{~mm}-775 \mathrm{~kg}$ per $1 \mathrm{~m}^{3}$ of fresh concrete mixture. The concretes were made without any additions and admixtures to exclude their effects on the measured volume changes.

The specimens were manufactured in a concrete mixer according to EN 12390-2 (37). Consistency of the fresh concrete was determined by slump cone according to EN 12350-2 (35), bulk density and air content in the fresh mixture were determined according to EN 12350-6 (38) and EN 12350-7 (39) as basic rheological parameters (as seen in Table 9) of fresh concretes with $100 \%$ mass content of H-Cement (HPC 1.00) and 100\% mass content of ordinary Portland cement (PCH 1.00).

Concretes from every batch were made in the form of prismatic specimens of $(100 \times 100 \times 400)$ $\mathrm{mm}$ dimensions for the testing of volume changes, dynamic modulus of elasticity and strength parameters within the period of 90 days at the given curing regimes and compressive strength testing on the cubes with a $150 \mathrm{~mm}$ edges after 28 days of basic curing in water at temperature of $20 \pm 1{ }^{\circ} \mathrm{C}$. The specimens were stored in water at temperature of $20 \pm 1{ }^{\circ} \mathrm{C}$ (indicated as W20), in air at temperature of
$20 \pm 1{ }^{\circ} \mathrm{C}$ with $60 \%$ of R. H. (A20) or air at temperature of $40 \pm 2{ }^{\circ} \mathrm{C}$ (A40) with R. H. of $15 \%$ as stated in Table 8.

Tests of volume changes in the hardened concretes were performed according to STN 731320 (40), those of the cube compressive and flexural strength according to EN 12390-3 (34) and EN 12390-5 (41), those of the bulk density and dynamic modulus of elasticity values were determined according to EN 12390-7 (42) and STN 731371 (43), respectively. Volume changes were measured on the basis of proportional, comparative length changes using prismatic specimens of size of $(100 \times 100 \times 400) \mathrm{mm}$ by the length comparator instrument according to STN 731320 (40).

\subsubsection{Measurements of volume changes}

Volume changes (expressed as length changes) of concretes made from OPC (PCH 1.00 marked as OPC-concrete), H-Cement (HPC-H 1.00 marked as $\mathrm{H}$-concrete) and mixtures of these two cements in the ratios shown in Table 8 ( $\mathrm{PCH} 0.85$ to 0.95 ), stored for 90 days in water at temperature of $20 \pm 1{ }^{\circ} \mathrm{C}$ after basic curing are illustrated in Figure 1. 


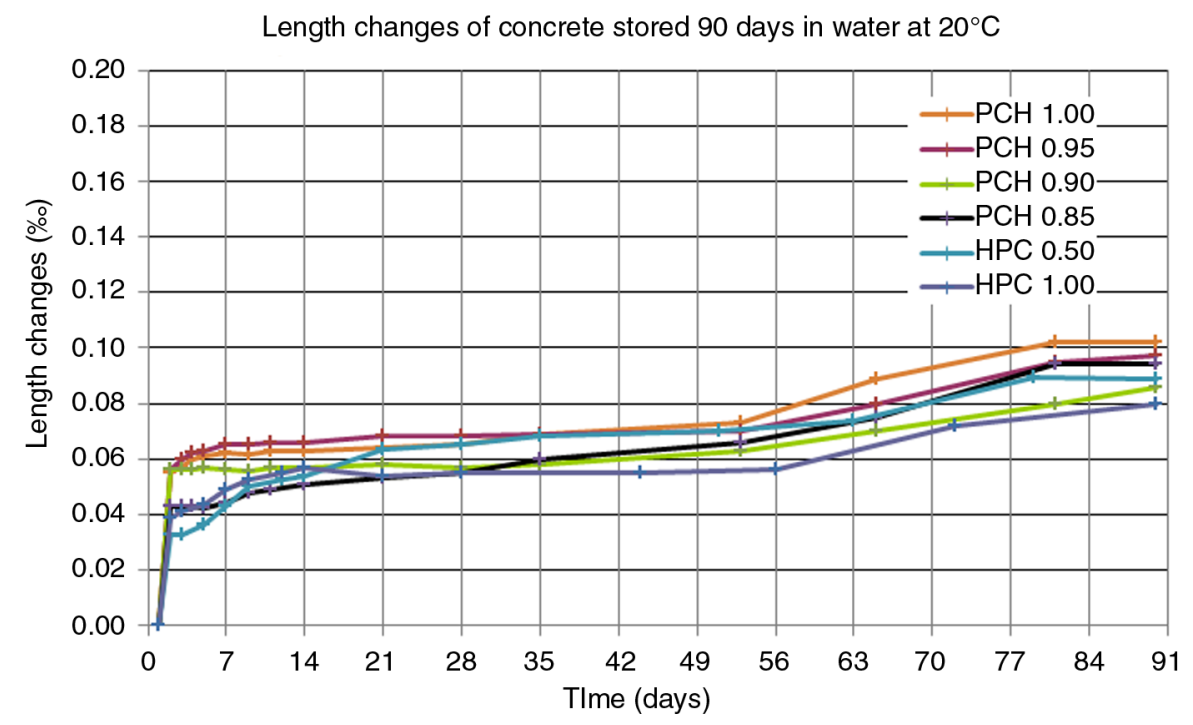

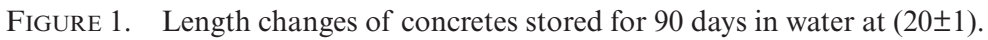

After the first day of immersion, rapid expansion was observed in all specimens: the concretes with 0 to 10 mass $\%$ of $\mathrm{H}-\mathrm{Cement}$ content expanded to the level of $0.056 \%$ while those containing 15,50 and 100 mass $\%$ of $\mathrm{H}-$ Cement only up to $0.04 \%$. The initial (zero) measurement is performed immediately after remoulding the green concrete 24 hours after its manufacturing in the laboratory. The rapid expansion within next 24-hours exposure in water is caused by the change of curing regime and attributed to a hydration of fresh concrete in favourable water environment. Consequently all concretes showed slight expansion with negligible deviations from the trend of moderate expansion. Initial 24-hours expansion represents approximately a half of the total value of the measured final 90-day's expansion. The largest difference in final expansion values is observed between H-concrete (HPC $1.00)$ and OPC-concrete (PCH 1.00): OPC-concrete expands of $0.102 \%$ while $\mathrm{H}$-concrete only $0.080 \%$. $\mathrm{H}$-Cement demonstrates slight expansion-reducing effect in the concrete compared to the effect of OPC.

Length changes of the concretes made of OPC (PCH 1.00), H-Cement (HPC 1.00) and concretes made of the above cement mixtures (HPC 0.85 to 0.95 ) stored for 90 days at temperature of $20 \pm 1{ }^{\circ} \mathrm{C} / 60 \%$ of $\mathrm{R}$. H. and temperature of $40 \pm 2){ }^{\circ} \mathrm{C} / 15 \%$ of R. H. - dry air are illustrated in Figures 2 and 3. Although all concretes shrink, significant difference among the measured values primarily depends on the used cement and cement mixture, respectively.

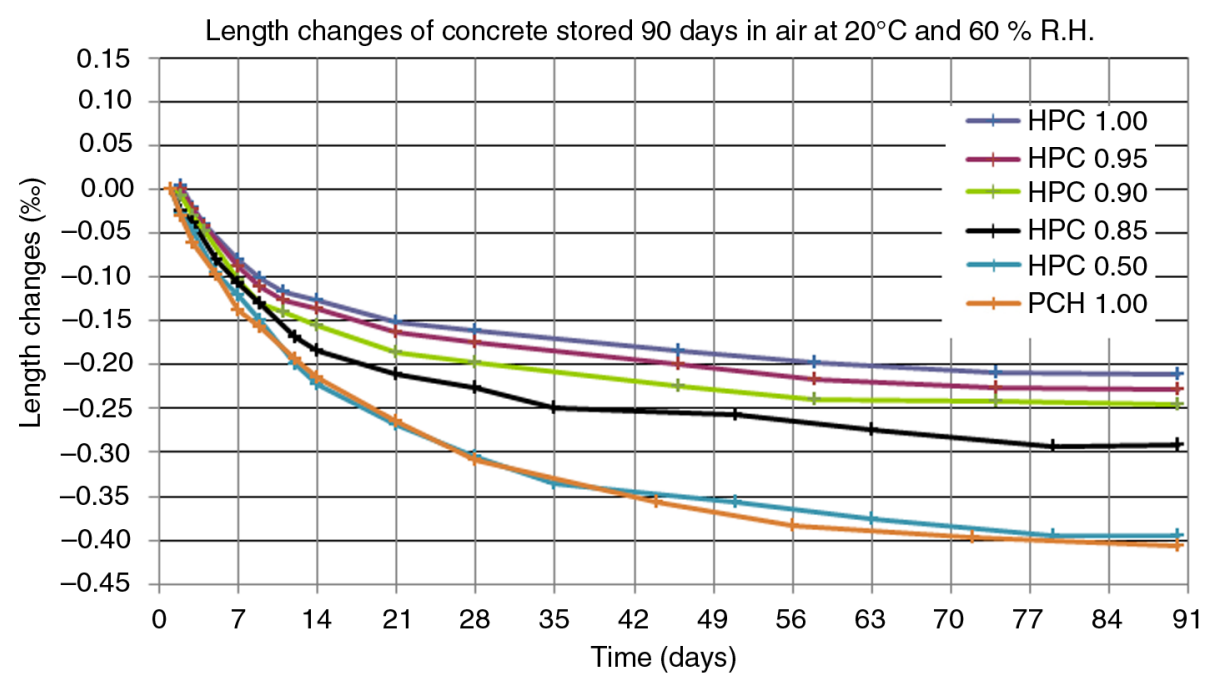

FIGURE 2. Length changes of concrete stored for 90 days in $(20 \pm 1){ }^{\circ} \mathrm{C} 60 \%$ R.H. - air. 
Length changes of concrete stored 90 days in air at $40^{\circ} \mathrm{C}$

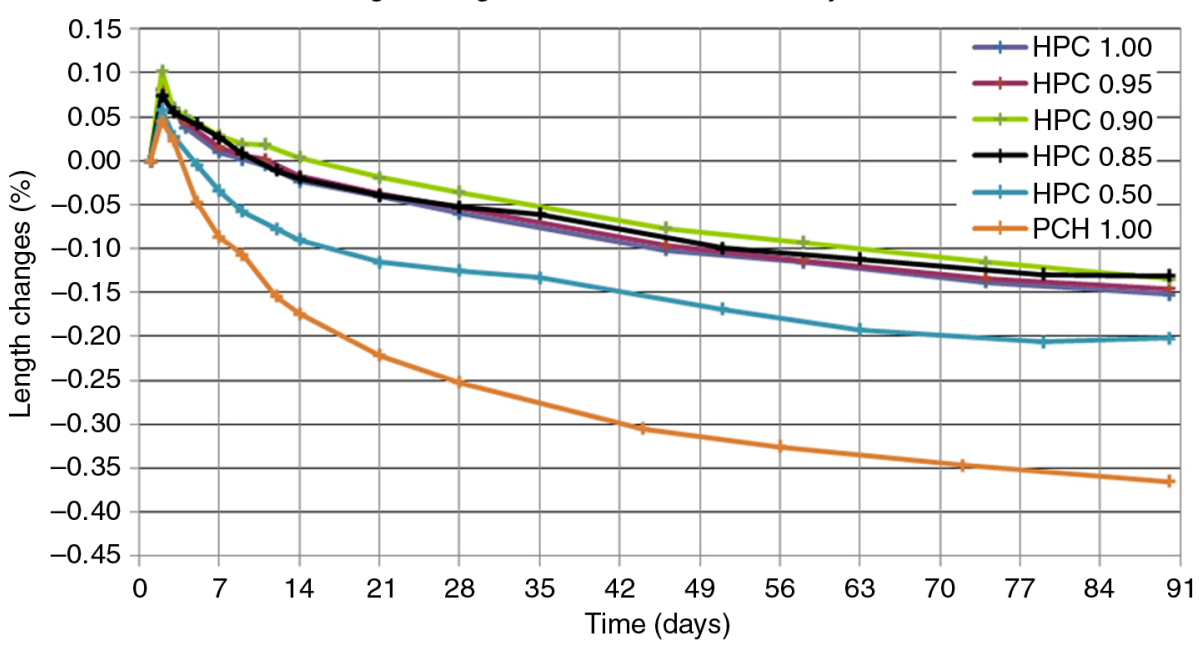

FigURE 3. Length changes of concrete stored for 90 days in $\left(40 \pm 2{ }^{\circ} \mathrm{C}\right) / 15 \% \mathrm{R}$. H. - air.

Particular concretes shrink differently in air at temperature of $20 \pm 1^{\circ} \mathrm{C}$ and $60 \%$ of R.H. (Figure 2). $\mathrm{H}$-concrete (HPC 1.00) shrinks the least of all and OPC-concrete (PCH 1.00) the most of all. After 90-days exposure in air at temperature of $20 \pm 1{ }^{\circ} \mathrm{C}$, OPC- concrete shrinks up to $-0.406 \%$ while $\mathrm{H}$-concrete to the half level of $-0.211 \%$ only. This fact proves evident shrinkage-reducing property of $\mathrm{H}$-Cement. The more H-Cement in the concrete is, the less shrinks at $20 \pm 1{ }^{\circ} \mathrm{C} / 60 \%$ of R. H. - dry air cure. Higher content of $\mathrm{H}$-Cement in concrete causes larger reduction in shrinkage. This effect is the most apparent at 100 mass $\%$ of H-Cement content due to containing only of 19.30 mass \% clinker minerals. The concrete containing 50\% OPC (53.45 mass $\%$ of clinker minerals) shrinks equally as the concrete with $100 \%$ OPC content ( 87.59 mass $\%$ of clinker minerals).

Development of length changes of concretes stored for 90 days at temperature of $40 \pm 2{ }^{\circ} \mathrm{C} / 15 \%$ of R. H. -dry air (Figure 3) are similar to those observed at temperature of $20 \pm 1{ }^{\circ} \mathrm{C}$ at $60 \%$ of
R.H.-air cure. OPC-concrete shrinks most intensively from all examined specimens. The more $\mathrm{H}$-Cement in the concrete is, the less shrinks at $40 \pm 1{ }^{\circ} \mathrm{C} / 15 \%$ of R. H. - dry air cure. In contrast with results at temperature of $20 \pm 1{ }^{\circ} \mathrm{C} / 60 \%$ of $\mathrm{R}$. $\mathrm{H}$. - air cure, shrinkage is reduced at temperature of $40 \pm 2{ }^{\circ} \mathrm{C} / 15 \%$ of R. H. - dry air also at $50 \%$ of OPC substitution by $\mathrm{H}$-Cement in the cement mixture. All concretes containing more than $90 \% \mathrm{H}$-Cement ( $\geq 81$ mass \% of clinker minerals) in a cement mixture with OPC shrink in warm and extremely dry air approximately equally.

\subsubsection{Determination of mechanical properties}

Mechanical properties of the studied concretes stored for 28 and 90 days in water at temperature of $20 \pm 1{ }^{\circ} \mathrm{C}$ (W20) and air at temperature of $20 \pm 1{ }^{\circ} \mathrm{C} / 60 \%$ of R. H. (A20) or temperature of $40 \pm 2{ }^{\circ} \mathrm{C} / 15 \%$ of R. H. (A40) after initial 28-days basic curing (BC) are reported in Tables 10, 11 and 12.

TABLE 10. Mechanical properties of the concretes made from a mixture of $\mathrm{H}-\mathrm{Cement}$ and OPC stored for 90 days in water at $(20 \pm 1){ }^{\circ} \mathrm{C}$ (W20) after 28-days basic curing

\begin{tabular}{|c|c|c|c|c|c|c|c|}
\hline \multicolumn{2}{|c|}{ Concrete kind } & \multicolumn{4}{|c|}{ After 90 days in water at $20^{\circ} \mathrm{C}$} & \multicolumn{2}{|c|}{ After 28-days BC } \\
\hline Concrete mixture & $\begin{array}{c}\text { Content of } \\
\text { H-Cement in } \\
\text { concrete (mass \%) }\end{array}$ & $\begin{array}{c}\text { Dynamic modulus } \\
\text { of elasticity } \\
\text { (GPa) }\end{array}$ & $\begin{array}{l}\text { Flexural } \\
\text { strength } \\
\text { (MPa) }\end{array}$ & $\begin{array}{l}\text { Strength at } \\
\text { the ends of } \\
\text { prism (MPa) }\end{array}$ & $\begin{array}{c}\text { Bulk density } \\
\left(\mathrm{kg} / \mathrm{m}^{3}\right)\end{array}$ & $\begin{array}{c}\text { Cube strength } \\
\text { (MPa) }\end{array}$ & $\begin{array}{c}\text { Bulk density } \\
\left(\mathrm{kg} / \mathrm{m}^{3}\right)\end{array}$ \\
\hline HPC $1.00 \mathrm{~W} 20$ & 100 & 46.6 & 5.4 & 34.2 & 2330 & 27.2 & 2340 \\
\hline HPC $0.50 \mathrm{~W} 20$ & 50 & 50.3 & 5.5 & 49.1 & 2350 & 35.7 & 2370 \\
\hline PCH 0.85 W20 & 15 & 55.1 & 5.5 & 50.6 & 2380 & 40.5 & 2390 \\
\hline PCH $0.90 \mathrm{~W} 20$ & 10 & 55.9 & 5.5 & 50.7 & 2380 & 40.5 & 2390 \\
\hline PCH 0.95 W20 & 5 & 56.6 & 5.5 & 51.4 & 2390 & 41.0 & 2400 \\
\hline $\mathrm{PCH} 1.00 \mathrm{~W} 20$ & 0 & 56.5 & 5.5 & 54.5 & 2390 & 41.6 & 2400 \\
\hline
\end{tabular}

Notice: Basic curing (abbreviated as BC) is specified by 1 - day cure in the chamber at $(20 \pm 1){ }^{\circ} \mathrm{C}$ at $100 \%$ R.H.-air and 27 - days curing in water at $(20 \pm 1)^{\circ} \mathrm{C}$. 
TABLE 11. Mechanical properties of the concretes made from a mixture of H-Cement and OPC stored for 90 days in air at $20^{\circ} \mathrm{C} / 60 \% \mathrm{R}$. H. (A20) after 28-days basic curing

\begin{tabular}{|c|c|c|c|c|c|c|c|}
\hline \multicolumn{2}{|c|}{ Concrete kind } & \multicolumn{4}{|c|}{ After 90 days in air at $20^{\circ} \mathrm{C}$} & \multicolumn{2}{|c|}{ After 28-days BC } \\
\hline Concrete mixture & $\begin{array}{c}\text { Content of } \\
\text { H-Cement in } \\
\text { concrete (mass \%) }\end{array}$ & $\begin{array}{c}\text { Dynamic modulus } \\
\text { of elasticity } \\
\text { (GPa) }\end{array}$ & $\begin{array}{c}\text { Flexural } \\
\text { strength } \\
\text { (MPa) }\end{array}$ & $\begin{array}{c}\text { Strength at } \\
\text { the ends of } \\
\text { prism (MPa) }\end{array}$ & $\begin{array}{c}\text { Bulk density } \\
\left(\mathrm{kg} / \mathrm{m}^{3}\right)\end{array}$ & $\begin{array}{l}\text { Cube strength } \\
\text { (MPa) }\end{array}$ & $\begin{array}{c}\text { Bulk density } \\
\left(\mathrm{kg} / \mathrm{m}^{3}\right)\end{array}$ \\
\hline $\mathrm{HPC} 1.00 \mathrm{~A} 20$ & 100 & 41.7 & 2.4 & 32.3 & 2270 & 27.6 & 2280 \\
\hline HPC 0.95 A 20 & 95 & 41.4 & 2.8 & 32.9 & 2270 & 29.3 & 2290 \\
\hline HPC 0.90 A 20 & 90 & 41.3 & 2.9 & 34.8 & 2270 & 31.3 & 2300 \\
\hline HPC 0.85 A 20 & 85 & 41.4 & 3.0 & 37.2 & 2270 & 32.4 & 2310 \\
\hline HPC 0.50 A 20 & 50 & 41.2 & 3.3 & 41.0 & 2290 & 38.1 & 2320 \\
\hline PCH 1.00 A20 & 0 & 39.3 & 3.7 & 42.0 & 2310 & 40.2 & 2330 \\
\hline
\end{tabular}

TABLE 12. Mechanical properties of the concretes made from a mixture of $\mathrm{H}-\mathrm{Cement}$ and OPC stored for 90 days in air at $40^{\circ} \mathrm{C} / 15 \%$ R. H. (A40) after 28 -days basic curing

\begin{tabular}{|c|c|c|c|c|c|c|c|}
\hline \multicolumn{2}{|c|}{ Concrete kind } & \multicolumn{4}{|c|}{ After 90 days in air at $40^{\circ} \mathrm{C}$} & \multicolumn{2}{|c|}{ After 28-days BC } \\
\hline Concrete mixture & $\begin{array}{c}\text { Content of } \\
\text { H-Cement in } \\
\text { concrete (mass \%) }\end{array}$ & $\begin{array}{c}\text { Dynamic modulus } \\
\text { of elasticity } \\
\text { (GPa) }\end{array}$ & $\begin{array}{l}\text { Flexural } \\
\text { strength } \\
\text { (MPa) }\end{array}$ & $\begin{array}{l}\text { Strength at } \\
\text { the ends of } \\
\text { prism (MPa) }\end{array}$ & $\begin{array}{c}\text { Bulk density } \\
\left(\mathrm{kg} / \mathrm{m}^{3}\right)\end{array}$ & $\begin{array}{c}\text { Cube strength } \\
\text { (MPa) }\end{array}$ & $\begin{array}{c}\text { Bulk density } \\
\qquad\left(\mathrm{kg} / \mathrm{m}^{3}\right)\end{array}$ \\
\hline HPC $1.00 \mathrm{~A} 40$ & 100 & 36.7 & 2.3 & 30.6 & 2220 & 28.7 & 2270 \\
\hline HPC 0.95 A 40 & 95 & 36.7 & 2.4 & 31.8 & 2220 & 30.0 & 2270 \\
\hline НPC 0.90 A 40 & 90 & 36.7 & 2.5 & 33.0 & 2220 & 32.0 & 2280 \\
\hline HPC 0.85 A40 & 85 & 36.6 & 2.6 & 34.7 & 2220 & 33.2 & 2290 \\
\hline $\mathrm{HPC} 0.50 \mathrm{~A} 40$ & 50 & 36.5 & 3.2 & 38.5 & 2240 & 38.5 & 2300 \\
\hline PCH $1.00 \mathrm{~A} 40$ & 0 & 33.4 & 3.8 & 39.0 & 2260 & 39.1 & 2300 \\
\hline
\end{tabular}

The bulk density of concrete is slightly reduced from the $85 \%$ mass portion of $\mathrm{H}$-Cement in the cement mixture in both dry exposures; however this decrease is insignificant. In water the bulk density decreases continuously but also very negligibly. The compressive strength clearly decreases with a 50 mass $\%$ and higher $\mathrm{H}$-Cement portion in the cement mixture in dry air cure while continual increase is observed underwater.

The 90-days bulk density and flexural strength of the concrete slightly decreases with increasing of $\mathrm{H}$-Cement portions in the cement mixture at all three curing regimes, with the exception of the unchanged flexural strength of concrete kept permanently in water. Compressive strength at the ends of the $(100 \times 100 \times 400) \mathrm{mm}$ prisms apparently decreases with 50 mass $\%$ and higher $\mathrm{H}-\mathrm{Cement}$ portion in the cement mixture.

Mutual dependences between length changes and compressive strength developments of the concretes and $\mathrm{H}$-Cement contents permanently kept in water and dry environments (as seen in Figure 4) demonstrate the following important findings:

1.) the cement composition has significant influence on the compressive strength uptakes, while negligible on the achieved expansions at temperature of $20 \pm 1{ }^{\circ} \mathrm{C}$ - water cure; the expansion of H-Cement is slightly reduced contrary to that of OPC.

2.) the cement composition has significant influence on both studied parameters: linear dependence between shrinkage reduction levels and compressive strength losses is confirmed. Higher $\mathrm{H}$-cement content in the cement mixture gives the concrete of lower shrinkage and compressive strength values. The results indicate possible adjusting of shrinkage rate and strength development to an expected level by the targeted mixing of H-CEMENT with OPC at temperature of $20 \pm 1{ }^{\circ} \mathrm{C} / 60 \%$ of R.H. - air cure.

3.) the cement composition has significant influence on compressive strength uptakes at 50\% substitution of OPC by $\mathrm{H}-\mathrm{Cement}(38.5 \mathrm{MPa})$ that is very similar to that of OPC-concrete $(39,0 \mathrm{MPa})$ but clearly increased relative to $\mathrm{H}$-concrete (30.6 MPa), while length changes are approximately half of the level achieved by OPC at temperature of $40 \pm 2{ }^{\circ} \mathrm{C} / 15 \%$ of R.H - air cure.

4.) the concrete containing of 85 mass $\%$ of $\mathrm{H}$-Cement is characterized by the same shrinkage than that observed in $\mathrm{H}$-concrete but its compressive strength is about $12 \%$ higher at temperature of $40 \pm 2{ }^{\circ} \mathrm{C} / 15 \%$ of R.H - dry air cure. 


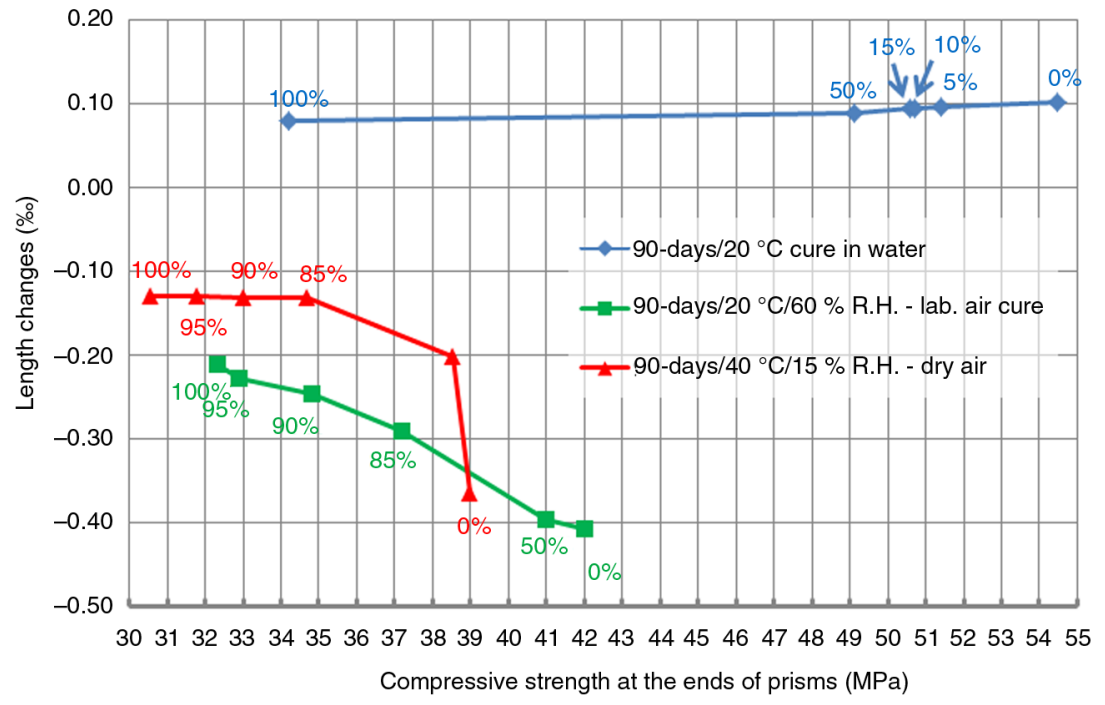

FIGURE 4. The dependence between length changes of the concrete with different $\mathrm{H}$-Cement content in cement mixtures and the compressive strength at the ends of specimens after 90 days of different curing regimes.

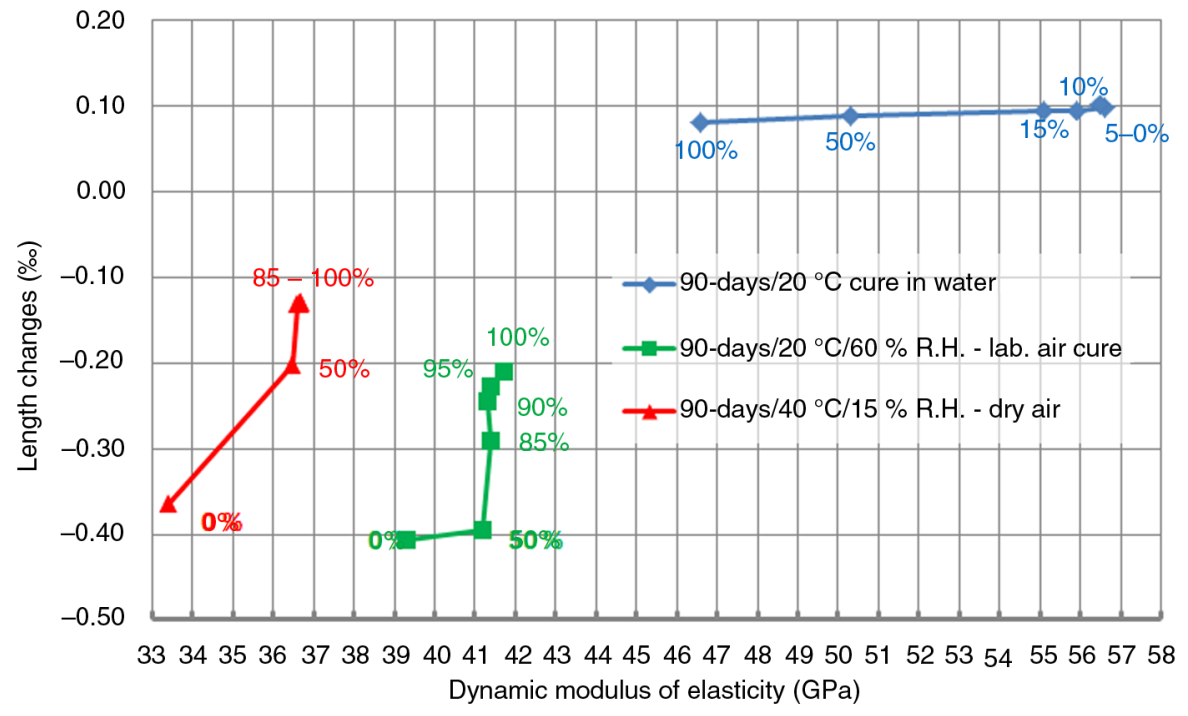

FiguRE 5. The coherence between the length changes of concrete with different $\mathrm{H}-\mathrm{Cement}$ content in cement mixtures and the dynamic modulus of elasticity after 90 days of different curing regimes.

Mutual dependences between length changes and dynamic modulus of elasticity developments of the concretes and H-Cement contents in the cement mixtures permanently kept in water and dry environments (Figure 5) result in:

1.) the same dependence as observed for strength behaviours at temperature of $20 \pm 1^{\circ} \mathrm{C}$ - water cure.

2.) the effect of cement composition is quite different on dynamic modulus elasticity values relative to that on compressive strengths at temperature of $20 \pm 1{ }^{\circ} \mathrm{C} / 60 \%$ of R. H. - air cure. The concrete with 50 mass \% substitution of OPC by H-Cement shows elasticity modulus increase approximately $2 \mathrm{GPa}$ opposite to OPC concrete at approximately the same shrinkage level. Next increase in H-Cement content in the mixture leads to pronounced shrinkage reductions without any noticeable change in dynamic modulus of elasticity.

3.) the effect of cement composition is also quite different on dynamic modulus elasticity values relative to that on compressive strengths at 
temperature of $40 \pm 2{ }^{\circ} \mathrm{C} / 15 \%$ of R. H. -dry air cure. The concrete with $50 \%$ of OPC substitution by $\mathrm{H}$-Cement shows elasticity modulus increase approximately $3 \mathrm{GPa}$ opposite to OPC concrete but length changes are approximately half of the level achieved with only OPC at temperature of $40 \pm 2{ }^{\circ} \mathrm{C} / 15 \%$ of R.H. -dry air cure. Next increase in H-Cement content in the mixture leads to continual shrinkage reductions without any noticeable changes in dynamic modulus of elasticity.

\subsubsection{Influence of cement mineralogical compositions on concrete behaviour}

The aim of this part of study is to demonstrate positive effect of 80 mass $\%$ of Portland cement clinker substitutions in hybrid cement by inorganic geopolymer on shrinkage reduction of concrete kept in dry air at the ambient temperature of $20^{\circ} \mathrm{C}$ and elevated temperature of $40^{\circ} \mathrm{C}$. Detailed study of the binder phase of the $\mathrm{H}$-Cement is the actual subject of the on-going fundamental research. The dependence between length changes of concrete after 90-days of different exposures and the content of clinker minerals in the cement mixtures is illustrated in Figure 6.

These main observations are derived from the above findings:

- H-concrete expands at temperature of $20 \pm 1{ }^{\circ} \mathrm{C}$ water by $0.022 \%$ less than OPC-concrete showing total expansion of $+0.102 \%$ o

- H-concrete shrinks in air at temperature of $20{ }^{\circ} \mathrm{C} / 60 \%$ of R. H. by $0.192 \%$ less than OPCconcrete showing total shrinkage of $-0.406 \%$ o
- H-concrete shrinks in air at temperature of $40{ }^{\circ} \mathrm{C} / 15 \% \mathrm{R}$. H. by $0.213 \%$ less than OPCconcrete showing total shrinkage of $-0.365 \%$ o

- slight expansion-reducing and pronounced shrinkage-reducing property of $\mathrm{H}$-Cement is confirmed

- expansion in water and shrinkage in air is caused by 19.30 mass \% content of clinker minerals present in H-CEMENT opposite to 87.59 mass $\%$ in OPC

- if clinker minerals content exceeds 50 mass \% in the cement mixtures, the shrinkage of concrete is dominantly influenced by OPC at temperature of $20^{\circ} \mathrm{C} / 60 \%$ of R. H. - air cure

- if clinker minerals content falls below 30 mass \% in the cement mixtures, the shrinkage of concrete is dominantly influenced by H-CEMENT at temperature of $40{ }^{\circ} \mathrm{C} / 15 \%$ of R. H. - dry air cure.

\section{CONCLUSIONS}

The following conclusions are applicable to the particular test cements and test methods employed:

1.) H-Cement is suitable for the production of ready-mixed concrete compressive strength classes up to $\mathrm{C} 30 / 37$. The plasticizer to achieve extended workability is based on lignosulfonate or polycarboxylate base; the most plasticity efficiency gives the combination of both admixtures.

2.) The expansion of concrete containing H-Cement is reduced by $21.6 \%$ compared to OPC concrete of the same composition after 90-days cure at water of temperature of $20 \pm 1^{\circ} \mathrm{C}$

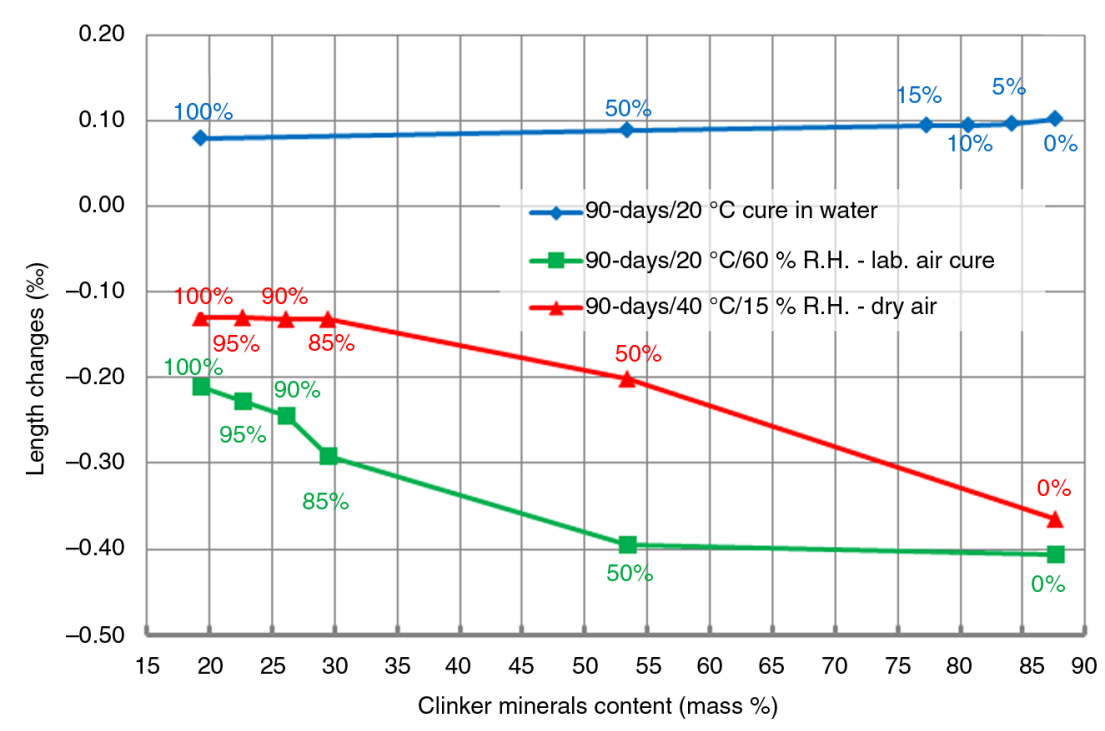

Figure 6. The dependence of length changes of concrete on the content of clinker minerals in tested cement mixtures. 
3.) The shrinkage of concrete containing H-Cement kept for 90 days temperature of $20^{\circ} \mathrm{C} / 60 \%$ of R.H. and $40{ }^{\circ} \mathrm{C} / 15 \%$ of R.H. - air is reduced by $48.0 \%$ and $58.4 \%$ compare to OPC concrete.

4.) Shrinkage-reducing character of $\mathrm{H}$-Cement is primarily caused by $68.29 \%$ drop in clinker minerals content relative to that in OPC.

5.) The influence of admixtures on the shrinkage reducing property of $\mathrm{H}$-Cement is excluded because the concretes contain no any plasticizing admixture.

6.) Substitution of OPC by lower-strength $\mathrm{H}$-Cement resulted in no significant decline in the technically important properties, such as compressive strength and dynamic modulus of elasticity.

7.) To explain all the factors affecting main utility properties of innovative hybrid cement, a deeper research insight into the mechanism of microstructure and pore structure formation is presently conducted with industrial pilot applications.

\section{ACKNOWLEDGEMENT}

This paper was prepared also thank to support of "Bilateral Fund at National Level for 2014" in the Environmental thematic component with the Measurement code BFNENV4 belonging to a grant from EEA and Norway Grants.

\section{REFERENCES}

1. The European Cement Association (CEMBUREAU) (2014) Activity report 2013. D/2014/5457, Brussels, Belgium.

2. Gartner, E. (2004) Industrially interesting approaches to "low- $\mathrm{CO}_{2}$ " cements. Cem. Concr. Res. 34 [9], 1489-1498. http://dx.doi.org/10.1016/j.cemconres.2004.01.021.

3. Schneider, M. (2011) $\mathrm{CO}_{2}$-Minderung Weltweite Anforderungen. Proceed. Technisch WissenschaftlicheZementtagung. 1-27. (Düsseldorf, Germany).

4. Ádám J. (2011) The Kolontár Report. Causes and lessons from the red mud disaster, Benedek János Printing Cypress Ltd. Publisher Greens, Hungary.

5. Sahu, R.C.; Patel R.; Ray, B.C. (2010) Neutralization of red mud using $\mathrm{CO}_{2}$ sequestration cycle. J. Hazard. Mater. 179 [1-3], 28-34. http://dx.doi.org/10.1016/j.jhazmat.2010.02.052.

6. Strigáč, J.; Martauz, P. (2012) Combined binder on the base of wastes. Patent application SK PP 50024-2012.

7. Palomo, A.; Krivenko, P.; García-Lodeiro, I.; Kavalerova, E.; Maltseva, O.; Fernández-Jimenénez, A. (2014) A review on alkaline activation: new analytical perspectives. Mater. Construcc. 64 [315] Article number e022. http://dx.doi. org/10.3989/mc.2014.00314

8. García-Lodeiro, I.; Maltseva, O.; Palomo, A.; FernándezJiménez, A. (2012) Hybrid alkaline cements. Part I: Fundamentals. Roman J. Mater. 42 [4], 330-335. WOS: 000313318800002

9. Palomo, A.; Maltseva, O.; García-Lodeiro, I.; FernándezJiménez, A. (2013) Hybrid alkaline cements. Part II: The clinker factor. Roman J. Mater. 43 [1], 74-80. WOS: 000316506900011.

10. Fernández-Jiménez, A.; García-Lodeiro, I.; Donatello, S.; Maltseva, O.; Palomo, A. (2014) Specific examples of hybrid alkaline cements. Proceed. MATEC Web of Conferences, 11 [01001], 1-3.
11. Fernández-Jimenénez, A.; Sobrados, I.; Sanz, I.; Palomo, A. (2011) Hybrid cements with very low OPC content. Proceed. $13^{\text {th }}$ international congress on the chemistry of cement. Book of Abstracts, Area 3, Session 13, 141. (Madrid, Spain).

12. Bernal, S.A.; Herfort, D.; and Skibsted, J. (2011) Hybrid binders based on alkali sulfate-activated Portland clinker and metakaolin. Proceed. $13^{\text {th }}$ international congress on the chemistry of cement. Book of Abstracts, Area 3, Session 13, 142. (Madrid, Spain).

13. Zibouche, F.; Fernández-Jimenénez, A.; Boudissa, N.; Abadlia, M.T.; Palomo, A. (2011) Alkaline activation of metakaolin-slag-clinker blends. Proceed. $13^{\text {th }}$ international congress on the chemistry of cement, Book of Abstracts, Area 3, Session 13, 143. 1-7. (Madrid, Spain).

14. Abdollahnejad, Z.; Torgal, P.; Barroso Aguiar, J. (2014) Compressive strength and microstructure of hybrid alkaline cements. Int. J. Civ. Arch. Struct. Constr. Eng. 8 [2], 221-227.

15. Davidovits, J. (2005) Geopolymer chemistry and sustainable development. The poly(sialate) terminology: a very useful and simple model for the promotion and understanding of green-chemistry. Proceed. $4^{\text {th }}$ world congress Geopolymer, 9-16. (Saint-Quentin, France).

16. Donatello, S.; Maltseva, O.; Fernández-Jimenez, A. Palomo, A. (2014) The early age hydration. Reactions of a hybrid cement containing a very high content of coal bottom ash. J. Am. Ceram. Soc. 97 [3], 929-937. http:// dx.doi.org/10.1111/jace.12751.

17. García-Lodeiro, I.; Fernández-Jiménez, A.; Palomo, A. (2013) Variation in hybrid cements over time. Alkaline activation of fly ash-portland cement blends. Cem. Concr. Res. 52 [10], 112-122. http://dx.doi.org/10.1016/j.cemconres. 2013.03.022.

18. Fernández-Jiménez, A.; Flores, E.; Maltseva, O.; GarcíaLodeiro, I.; Palomo A. (2013) Hybrid alkaline cements. Part III: Durability and industrial applications. Roman J. Mater. 43 [2], 195-200. WOS:000320638300009.

19. Donatello, S.; García-Lodeiro, I.; Fernández-Jimenez, A.; Palomo, A. (2014) Some durability aspects of hybrid alkaline cements. Proceed. MATEC Web of Conferences, 11 [01001], 1-3.

20. Janotka, I.; Bačuvčík, M.; Martauz, P.; Strigáč, J. (2014) Chemical resistance of novel hybrid cement in various aggressive solutions. Proceed. RILEM international workshop on performance-based specification and control of concrete durability. paper ID006, 17-24. (Zagreb, Croatia).

21. Cheng, T.W.; Chiu, J.P. (2003) Fire-resistant geopolymer produced by granulated blast furnace slag. Miners. Eng. 16 [3], 205-210. http://dx.doi.org/10.1016/S0892-6875(03) 00008-6.

22. Palacios, M.; Puertas, F. (2007) Effect of shrinkage-reducing admixtures on the properties of alkali-activated slag mortars and pastes. Cem. Concr. Res. 37, [6], 691-702. http://dx.doi.org/10.1016/j.cemconres.2006.11.021.

23. Mehta, P.K.; Monteiro, P.J.M. (2013) Concrete: Microstructure, Properties, and Materials, Chapter 6.8.3. Expansive cements, Fourth edition, McGraw-Hill, 224-227.

24. CEN/TR 196-4 (2007) Methods of testing cement - Part 4: Quantitative determination of constituents.

25. EN 15167-1: 2006, Ground granulated blast furnace slag for use in concrete, mortar and grout - Part 1: Definitions, specifications and conformity criteria

26. Paul, M. (2005) Application of the Rietveld method in the cement industry. Proceed. Microstructure Analysis in Materials Science, 1-3. (Freiberg, Germany).

27. Schmidt, R.; and Eisenhowen, R. Laboratory Report XRD 65 Quantitative phase analysis of blast furnace slag cements, BRUKER AXS Internal material (https://www. bruker.com).

28. EN 14216 (2004) Cement. Composition, specifications and conformity criteria for very low heat special cements.

29. EN 196-1 (2005) Methods of testing cement. Part 1: Determination of strength. 
30. EN 197-1 (2011) Cement. Part 1: Composition, specification and conformity criteria for common cements.

31. SK Certificate of Conformity (2013) H-CEMENT No. SK04-ZSV-1800, TSÚS Bratislava.

32. Technical Approval (2013) H-CEMENT No. TO-13/0074, TSUS, Bratislava.

33. EN 206-1 (2000) Concrete. Part 1: Specification, performance, production and conformity.

34. EN 12390-3 (2009) Testing hardened concrete. Compressive strength of test specimens.

35. EN 12350-2 (2009) Testing fresh concrete. Slump-test.

36. STN 731311 (1986) Testing concrete mixture and concrete. Common provisions.
37. EN 12390-2 (2009) Testing hardened concrete. Making and curing specimens for strength tests.

38. EN 12350-6 (2009) Testing fresh concrete. Density.

39. EN 12350-7 (2009) Testing fresh concrete. Air content. Pressure methods.

40. STN 731320 (1987) Determination of volume changes of concrete.

41. EN 12390-5 (2009) Testing hardened concrete. Flexural strength of test specimens.

42. EN 12390-7 (2009) Testing hardened concrete. Density of hardened concrete

43. STN 731371 (1981) Method of ultrasonic pulse testing of concrete. 